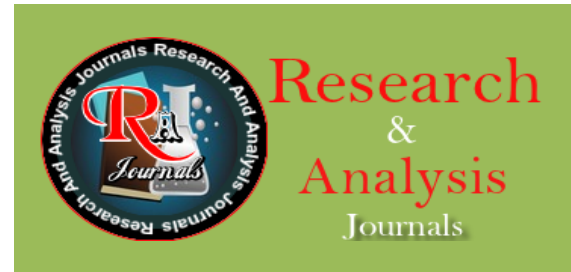

RA Journal of Applied Research

ISSN (e): 2394-6709

||Volume||3||Issue||12||Pages-1303-1314||December-2017||

Index Copernicus ICV: 74.25, DOI: 10.18535/rajar/v3i12.07

\title{
Leaf Phytognostic Characters of Six Species of Hypericum L. (Hypericaceae)
}

\author{
Generosa Teixeira ${ }^{1}$, Ana Monteiro ${ }^{2}$ \\ ${ }^{1}$ Center for Ecology, Evolution and Environmental Changes (CE3C), Faculdade de Farmácia, Universidade \\ de Lisboa, Av. Prof. Gama Pinto, 1649-003, Lisboa, Portugals \\ ${ }^{2}$ LinkingLandscape, Environment, AgricultureandFood (LEAF), Instituto Superior de Agronomia, \\ Universidade de Lisboa, Tapada da Ajuda, 1349-017 Lisboa, Portugal
}

\begin{abstract}
Most of the studies on Hypericum genus deals with the phytochemical and pharmacological properties and the morphoanatomical data are scarce, although sometimes some species are poorly identified. In order to obtain differentiating phytognostic characters, the micromorphological, anatomical and histochemical study of mature leaves of six Hypericum species, $\mathrm{H}$. androsaemum, $\mathrm{H}$. calycinum, $\mathrm{H}$. canariense, H. grandifolium, H. x inodorum and H. patulum, was carried out using different techniques of microscopy. Qualitative characters of both epidermal surfaces were evaluated: cell shape, cell wall, epicuticular deposits and stomata type. Only the last three characters showed some kind of differences. Five qualitative characters, stomata and gland indexes, total mesophyll thickness, palisade parenchyma and spongy parenchyma thickness, were subjected to analysis of variance on one factor ANOVA. Differences were found in the stomata and gland indexes as well as in the parenchyma cells arrangement and thickness. Histochemical tests were performed to localize and identify chemical groups of metabolites and the differences found were semi-quantitative. We conclude that the most important leaf phytognostic characters are: the epidermal cells shape, the type and distribution of stomata, the glands distribution and the mesophyll features.
\end{abstract}

Keywords: Hypericum, micromorphology, anatomy, leaf epidermal surface, mesophyll.

\section{INTRODUCTION}

The genus Hypericum L., Hypericaceae Juss. [1] is originated from Eurasia and is widely distributed in tropical and subtropical regions. It includes approximately 480 species, classified into 36 Sections [2]. Most Hypericum species show one or more different types of secretory structures in their vegetative and reproductive organs: dark glands, translucent glands and secretory channels [3-5]. It is at the level of these structures that the synthesis and accumulation of biologically active substances happens, for instance naphthodianthrones, flavonoids and phloroglucinol derivatives [6], to which important medicinal effects are attributed, such as antiretroviral and antidepressive action [7-8]. $\mathrm{H}$. perforatum L. (St. John's wort) is the most studied species and the only one recognized by occidental Pharmacopoeias, but there are some other species of Hypericum used as traditional medicinal plants to treat a variety of ailments [8-12]. The phytochemistry diversity and the bioactivity have been investigated in many species, but their morphological characteristics have been forgotten. However, due to geographical differences, apomictic reproduction modes [10] and the existence of several hybrids [13], the identification of some species might be difficult [14-17]. It is accepted that the micromorphological approach is more accurate, less environmental influenced, complementary to the macrocharacters and advisable in situations where the species limits is obscure [18]. 
H. androsaemum L. is one of the eleven Hypericum species found in continental Portugal [19-20]. In traditional medicine it is often used as a hepatic protective [21-22] instead of $\mathrm{H}$. perforatum. H. androsaemum is subject to misidentification and adulterations by other species, some of them introduced species but already naturalized, such as H. x inodorum Mill. and $H$. patulum Thunb. [22]. Reports on $\mathrm{H}$. androsaemum phytochemistry and bioactivities are known [21; 23-24] and also on chemotaxonomy involving this and other Portuguese species [25] but little is known about their phytognostic characters. Maggi et al., [17] and Perrone et al. [26] documented the morphology and histochemistry of Italian populations of $\mathrm{H}$. androsaemum. These authors mentioned that there are some differences in size and shape of leaves and flowers, type and distribution of the secretory structures on the herb's parts. The histochemical study allowed the localization of hypericin, flavonoids and essential oils. Hyperforin (that reaches the highest concentration in $H$. perforatum) is absent in H. androsaemum [17]. In this work we highlight six species: $H$. androsaemum, H. calycinum L., H. canariense L., H. grandifolium Choisy, H. x inodorum Mill. and H. patulum Thunb. They all are spontaneous or introduced shrubs, with morphologically similar leaves and sometimes are incorrectly identified and confused with each other. Their leaves do not have dark glands, they only show translucent glands. Considering that herbals usually are fragmented or even powdered, phytognostic characters can only be obtained by micromorphological examinations. These characters enable a comparative study and supply a valid criterion for species morphological differentiation, as well as the accurate and reproducible herbals quality control. That is the reason why microscopy data are part of the Pharmacopoeias plant monographs.

The present work reports the microscopic evaluation of mature leaves of the mentioned species, comparing their morphoanatomic and histochemical traits. To this end, imaging techniques such as scanning electron microscopy, conventional light and fluorescence microscopy, as well as staining techniques, were used.

\section{MATERIALS AND METHODS}

\section{Plant material}

H. androsaemum, H. calycinum, $H$. canariense, $H$. grandifolium, H. x inodorum and $\mathrm{H}$. patulum, were kept in culture in Parque Botânico of Tapada da Ajuda, Instituto Superior de Agronomia, University of Lisbon, Portugal. Shoots were collected before flowering and voucher specimens were deposited at the LISI Herbarium of ISA (Table 1). Each species was represented in the study by fifteen different fully expanded leaves, each one from a different shoot.

Table 1. Hypericum species identification.

\begin{tabular}{lll}
\hline Taxa & Section & Voucher (LISI) \\
\hline H. androsaemum L. & Androsaemum (Duh.) Godr. & $1864 / 2009$ \\
H. calycinum L. & Ascyreia Choisy Eremanthe (Spach) Blume & $1767 / 2009$ \\
H. canariensis L. & Webbia (Spach) R. Keller & $771 / 2008$ \\
H. grandifolium Choisy & Androsaemum (Duh.) Godr. & $1766 / 2009$ \\
H. x inodorum Mill. & Androsaemum (Duh.) Godr. & $773 / 2008$ \\
H. patulum Thunb. & Ascyreia Choisy & $363 / 2007$ \\
\hline
\end{tabular}




\section{Analysis of plant material}

A part of the plant material was cleared with chloral hydrate solution [27]. The observation of epidermal cells, stomata and gland distribution was estimated in the mid-lamina of both leaf epidermal surfaces. Stomata type followed Stace classification [18] and stomata index was found according to the European Pharmacopoeia 8.0 [27]. Histochemical tests and appropriate controls were performed on hand-sectioned fresh material: Sudan III for total lipids [28]; Nile Blue for neutral and acidic lipids [29]; $\mathrm{Cu}$ acetate / Rubeanic acid for fatty acids [30]; Nadi reagent for essential oils and resins [31]; 2,4Dinitrophenilhidrazin for terpenes with a carbonyl group [30]; Anthimonium chloride for steroids [32]; Ferric chloride and Potassium dichromate for phenolic compounds [28]; Vanillin/HCL for tannins [33]; Tannic acid./ferric chloride for mucilages and pectins [34]; PAS for polysaccharides [35]; Dittmar reagent for alkaloids [36]. Light microscopy observations were made with a Nikon Labophot 2 LM and images were obtained with a Nikon325 FX-35W camera. The histochemical characterization was complemented with auto fluorescence and induced fluorescence observations with aluminum trichloride as fluorochrome for poliphenols detection on an epi-fluorescence microscope Olympus BX60 with an image acquisition system using an Olympus DP 50.

Other part of the plant material was fixed for scanning electronic microscopy (SEM), according to the usual methods [37]. SEM observations were carried out at $15 \mathrm{kV}$ on a JSM-5220 LV, equipped with image acquisition. For anatomical studies the fixed plant material was processed with the paraffin micro technique and sections were stained with acidic phloroglucin [38]. All measurements and counts related with these micromorphological characteristics were done on random fields, always at comparable leaf situations and magnifications.

\section{Data analysis}

Data analysis was performed statistically using the SAS ${ }^{\circledR}$ program (SAS Institute, Cary, NC, USA). Data were subjected to analysis of variance on one factor ANOVA, with a significance level of $5 \%$.Means of morphological characters were separated using Fisher's Protected LSD test at the $5 \%$ level of significance.

\section{RESULTS AND DISCUSSION}

The comparative study of the epidermal surfaces of the examined species provided some elements for their recognition and selection (Table 2). Adaxial and abaxial epidermal cells have polygonal shape, with anticlinal cell walls almost straight (Table 2). Only H. androsaemum (Fig. 1A) and H. calycinum (Fig. 1B) showed slightly sinuous cell walls on both surfaces. Esau [39] assigns to the sinuous cell wall an important mechanical function, increasing the rigidity of the parietal cell to prevent collapse in case of water deficits and its occurrence might be considered as a result of difficult environmental conditions such as disability in light and humidity. In all the samples the epicuticular waxes were also noticed in the leaf epidermis as large platelets, randomly oriented, showing a similar distribution in both faces (Table 2), although denser on the adaxial side of $\mathrm{H}$. canariense (Fig. 1C), H. androsaemum and $H$. calycinum. Perrone et al., [26] mentioned that the cuticular ornamentations in $\mathrm{H}$. androsaemum are scarce and barely detected, which is not in agreement with the one found in our samples. 


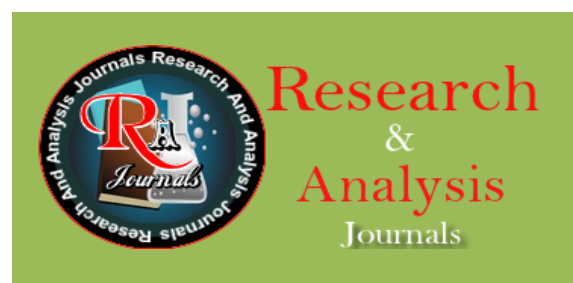

\section{RA Journal of Applied Research}

ISSN (e): 2394-6709

||Volume||3||Issue||12||Pages-1303-1314||December-2017||

Index Copernicus ICV: 74.25, DOI: 10.18535/rajar/v3i12.07

Table 2. Characters of the epidermal surface of the species of Hypericum under study. (HYPAN, H. androsaemum; HYPCA, H. calycinum; HYPCN, H. canariense; HYPGF, H. grandifolium; HYPIN, H. x inodorum; HYPPT, H. patulum; Ad., adaxial; Ab., abaxial; (+) slightly; (++) medium; (+++) high; nd, not defined).

\begin{tabular}{|c|c|c|c|c|c|c|}
\hline $\begin{array}{l}\text { Epidermal } \\
\text { surface } \\
\text { characters }\end{array}$ & HYPAN & HYPCA & HYPCN & HYPGF & HYPIN & HYPPT \\
\hline \multicolumn{2}{|c|}{ Ad. cell shape poligonal } & poligonal & poligonal & poligonal & poligonal & poligonal \\
\hline Ad. cell wall & sinuous $(+)$ & sinuous $(++)$ & straight & straight & Straight & sinuous $(+)$ \\
\hline Epicuticular & random & random & random & random & random & random \\
\hline Ad. Deposit & sorientated & orientated & orientated & orientated & orientated & orientated \\
\hline (density) & platelets $(+++)$ & platelets $(++)$ & platelets $(+++)$ & platelets $(+)$ & platelets $(+)$ & platelets (+) \\
\hline Ab. cell shape & poligonal & poligonal & poligonal & poligonal & poligonal & papillate \\
\hline Ab. cell wall & sinuous $(++)$ & sinuous $(++)$ & sinuous $(++)$ & sinuous $(+)$ & sinuous $(+)$ & nd \\
\hline Epicuticular & random & random & random & random & random & random \\
\hline Ab. Deposit & sorientated & orientated & orientated & orientated & orientated & orientated \\
\hline & platelets $(+++)$ & $\begin{array}{l}\text { platelets } \\
(+++)\end{array}$ & $\begin{array}{l}\text { platelets } \\
(++)\end{array}$ & $\begin{array}{l}\text { platelets } \\
(++)\end{array}$ & platelets (+) & platelets (+) \\
\hline Ab. stomata & anomocytic & anisocytic & anomocytic & anomocytic & anomocytic & nd \\
\hline type & anisocytic & & anisocytic & brachyparacy & brachyparacytic & \\
\hline
\end{tabular}

All species show stomata in the abaxial epidermis (Table 2): anomocytic and anisocytic in $\mathrm{H}$. androsaemum (Fig. 1A) and $\mathrm{H}$. canariense; anisocytic in H. calycinum (Fig. 1B); anomocytic and brachyparacytic in H. grandifolium (Fig. 1D) and in $\mathrm{H}$. $\mathrm{x}$ inodorum; not defined in $\mathrm{H}$. patulum because this taxon showed convex epidermal cells forming small papilla which turns difficult the stomata observation and classification (Fig. 1E). Epidermis papillose was also reported in certain species of Hypericum by Metcalfe e Chalk [40]. These authors also mentioned that in this genus the stomata are usually confined to the lower surface, commonly surrounded by three or more cells and there are cases in which several types have been recorded in a single leaf, just like what we observed, with the exception of $\mathrm{H}$. calycinum. Perrone et al. [26] also refer that $H$. androsaemum is a hypostomatic species, displaying only anisocytic stomata, which is in disagreement with our observations. Some researchers consider that stomata index is useful in comparing leaves of different sizes and they agree that the leaf midlamina of the abaxial 


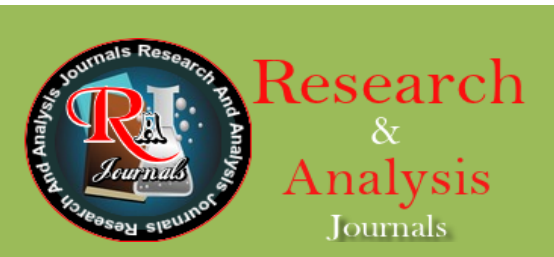

RA Journal of Applied Research

ISSN (e): 2394-6709

||Volume||3||Issue||12||Pages-1303-1314||December-2017||

Index Copernicus ICV: 74.25, DOI: 10.18535/rajar/v3i12.07
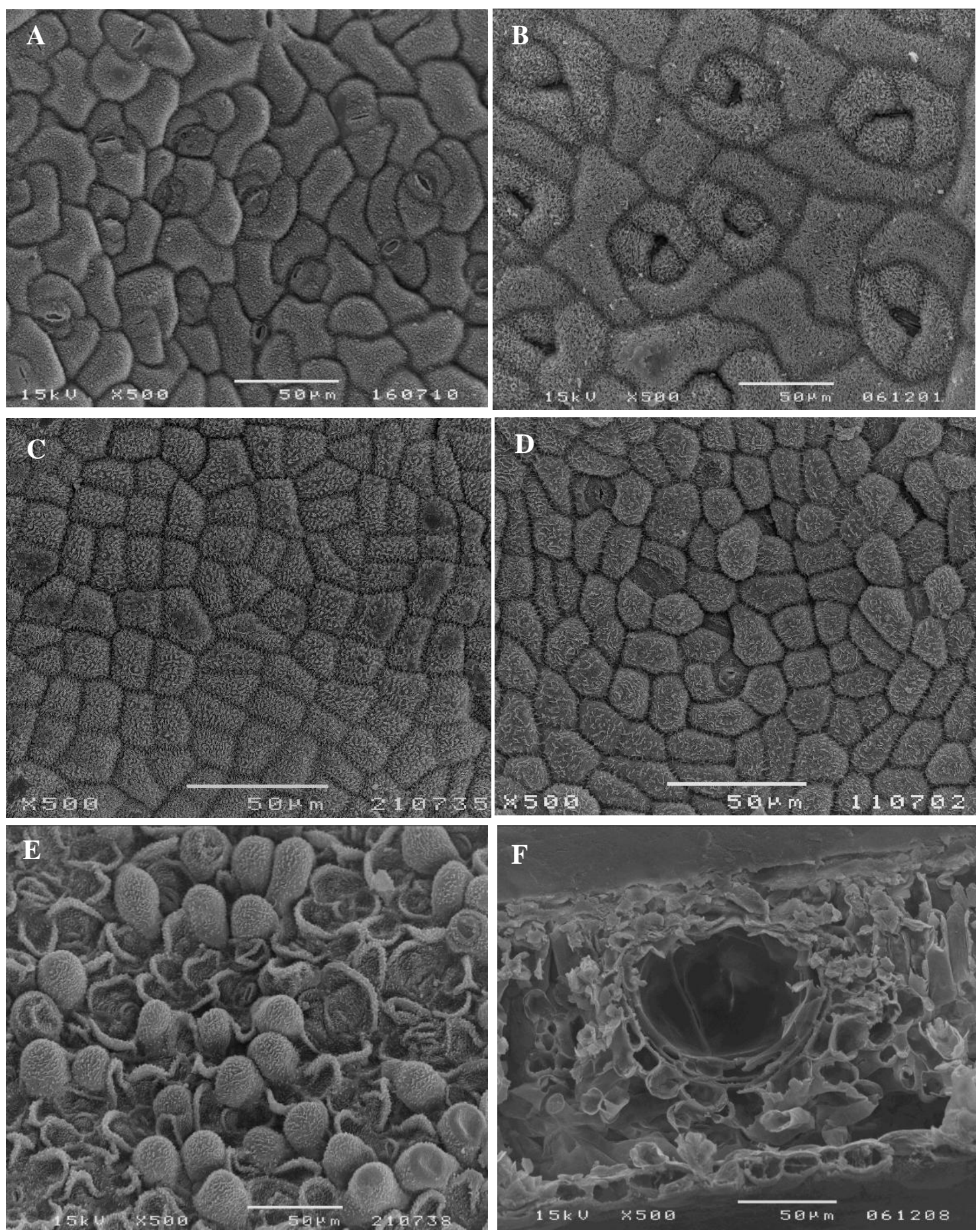

Figure 1. SEM micrographs of foliar epidermal surfaces: A - H. androsaemum abaxial epidermal cells, anomocytic and anisocytic stomata; B - H. calycinum abaxial epidermal cells and anisocytic stomata; C - H. canariense adaxial epidermal cells; D - H. grandifolium abaxial epidermal cells, anomocytic and brachyparacytic stomata (arrow); E - H. patulum abaxial epidermal papillate cells; F - H. calycinum leaf cross section with a cavity type internal secretory structure.

surface is the least variable and therefore most suitable for such measurements [Rowson in 41 ; 42; 18; 43]. Concerning the stomata index values, three groups were found, with $\mathrm{H}$. patulum being isolated with significant highest values, $\mathrm{H}$. 


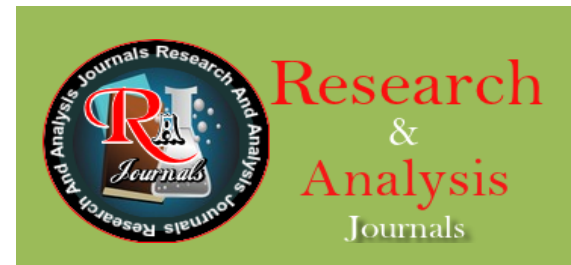

RA Journal of Applied Research

ISSN (e): 2394-6709

||Volume||3||Issue||12||Pages-1303-1314||December-2017||

Index Copernicus ICV: 74.25, DOI: 10.18535/rajar/v3i12.07

androsaemum significant lower values and the other four taxa with values in between (Fig. 2A).

The genus Hypericum can show different types of glandular structures in the aerial parts, translucent glands, secretory canals and black nodules, pointing to an intense secretory activity, but some species only have translucent glands in their leaves $[40 ; 44 ; 3-4 ; 17]$. The latter situation is found in all the studied taxa, where the glands are randomly distributed, usually small and more or less rounded in shape.

H. calycinum has the bigger translucent glands but their number was very low as the gland index was the lowest (1.0\%) among the species under study. On the opposite is H. canariense (Fig 2B) with the highest gland index (39.5\%). Glandular structures are genetic features of certain species, thus are formed without the influence of external factors but their density may or may not depend on external factors, such as injuries, pathogens or physiological stresses [45]. In transverse sections, the secretory glands were seen as cavities delimited by a flattened layer of secretory cells and by another external layer of rounded and thicker walled cells (Fig. 1F). They appear in the vicinity of the veins and sometimes in association with them. This suggests a certain connection between those two types of tissues [39]. As noticed on Table 3, there are no significant qualitative differences in the specimens' compounds. The secretion accumulated inside translucent glands stains positively for some lipophilic compounds: total lipids (Fig. 3A), acid lipids (Fig. 3B), fatty acids, essential oils (Fig. 3C) and for alkaloids (Fig. 3D). According to Costa [46], the positive results obtained for alkaloids should be interpreted with caution, since the reagents used can react with other different nitrogenous compounds such as proteins and amines. Steroids stained slightly positive just in H. patulum glands (Table 3 ). These results are somehow in accordance with some other studies on Hypericum that mention the presence of lipids and essential oils on translucent glands $[7 ; 44 ; 4$; 17; 47]. Phenolics were not detected inside of any species translucent glands at all and a similar situation was seen with the tannins, the mucilages and the polysaccharide histochemical tests (Table 3). In some situations their presence was noticed on cell walls of the cell layers limiting the glandular structures and on all the parenchyma cells (Fig. 3E). Under UV light sometimes slightly blue auto fluorescence was also noticed on the cells surrounding the translucent glands (Fig. 3F), pointing to the presence of some phenolic compounds. Some flavonoids are known to accumulate on leaf surfaces and play a role in the protection against UV radiation [48] which might explain the fact that they were more noticed on superficial glands.

Table 3. Histochemical tests on the content of the translucent glands of the Hypericum species studied. (HYPAN, H. androsaemum; HYPCA, H. calycinum; HYPCN, H. canariense; HYPGF, H. grandifolium; HYPIN, H. x inodorum; HYPPT, H. patulum; - negative; + slightly positive; ++ positive; +++ strongly positive; nd. not defined).

\begin{tabular}{lllllll}
\hline Histochemical Tests & HYPAN & HYPCA & HYPCN & HYPGF & HYPIN & HYPPT \\
\hline Sudan III (total lipids) & ++ & +++ & +++ & +++ & ++ & +++ \\
Nile Blue (acidic lipids) & ++ & +++ & +++ & +++ & ++ & +++ \\
Cu Acetat / Rubeanic ac. (fatty ac.) & ++ & + & + & + & + & nd.
\end{tabular}




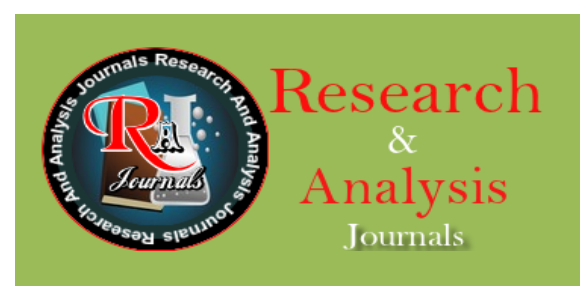

RA Journal of Applied Research

ISSN (e): 2394-6709

||Volume||3||Issue||12||Pages-1303-1314||December-2017||

Index Copernicus ICV: 74.25, DOI: 10.18535/rajar/v3i12.07

Nadi Reagent (essential oils and resins)
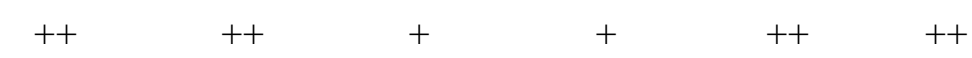

2,4- Dinitro-phenilhidrazin (terpenes)

Anthimonium chloride (steroids)

Ferric chloride (phenolics)

Potassium dichromate -

(phenolics)

Vanillin /HCL (tannins) -

Tannic ac./ferric +

chloride

(mucilages/pectins)

PAS (polysaccharides)

Dittmar Reagent

(alkaloids)
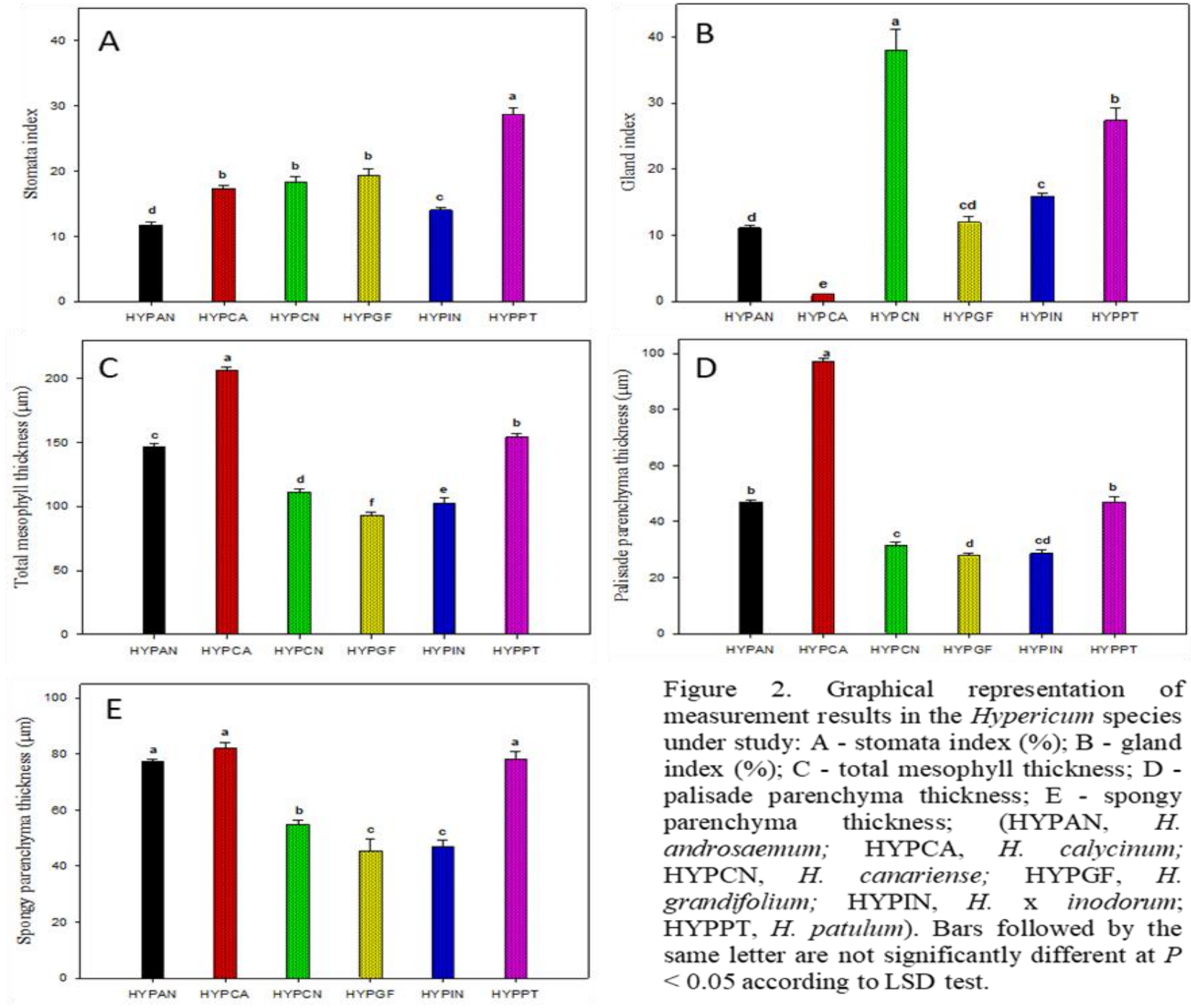

Figure 2. Graphical representation of measurement results in the Hypericum species under study: A - stomata index (\%); B - gland index (\%); C - total mesophyll thickness; D palisade parenchyma thickness; E - spongy parenchyma thickness; (HYPAN, $H$. androsaemum; HYPCA, H. calycimum; HYPCN, $H$. canariense; HYPGF, $H$. grandifolium; HYPIN, $H . \mathrm{x}$ inodorum; HYPPT, $H$. patulum). Bars followed by the same letter are not significantly different at $P$ $<0.05$ according to LSD test. 


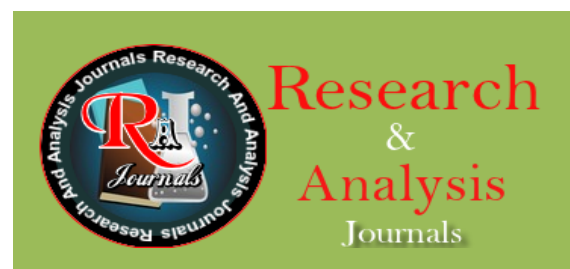

RA Journal of Applied Research

ISSN (e): 2394-6709

||Volume||3||Issue||12||Pages-1303-1314||December-2017||

Index Copernicus ICV: 74.25, DOI: 10.18535/rajar/v3i12.07
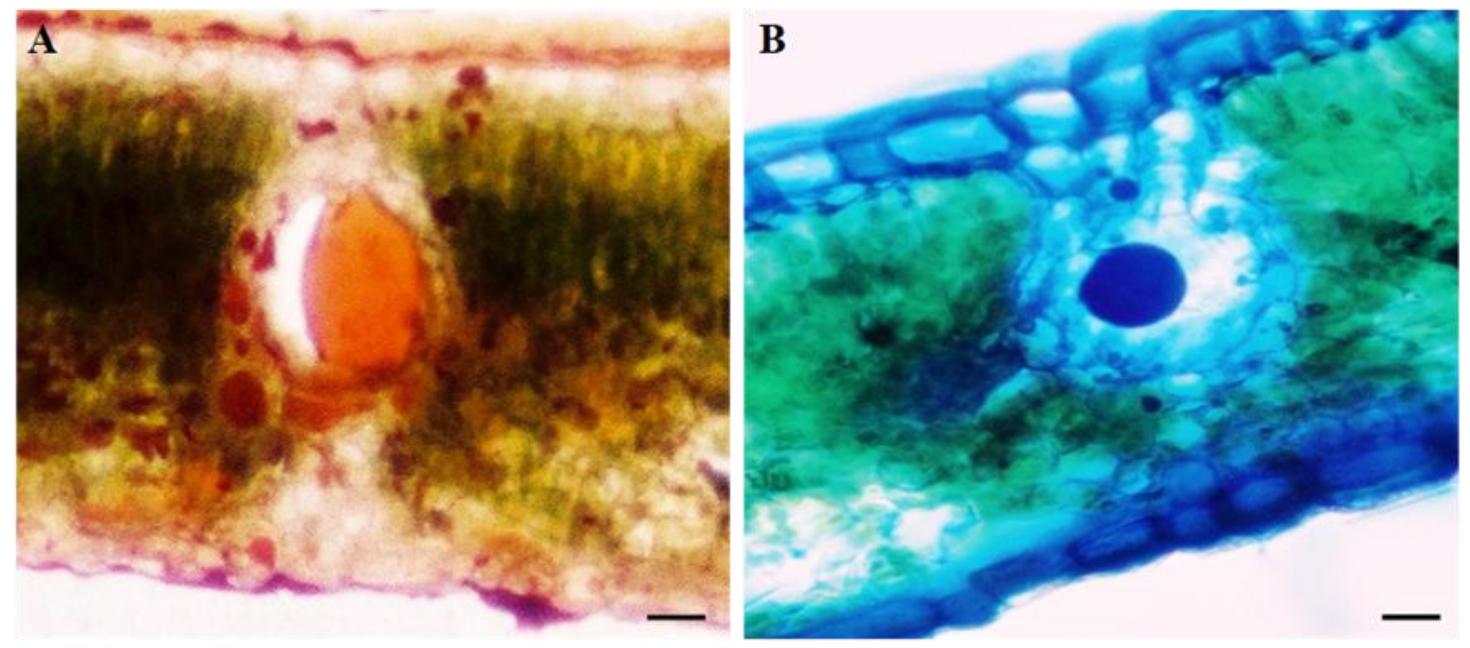

C

D
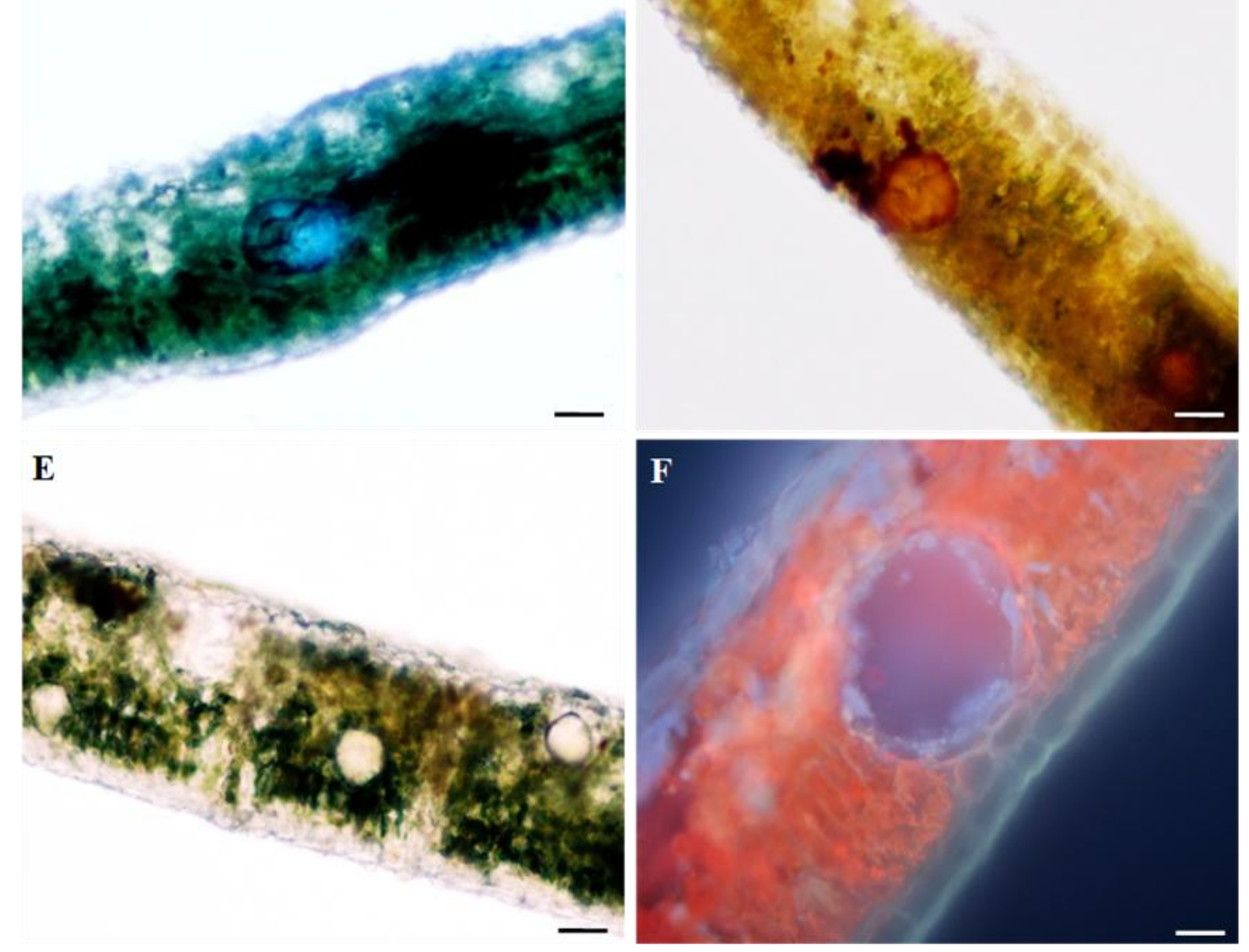

Figure 3. LM micrographs of leaves cross sections with internal secretory structures: A - $H$. calycifolium Sudan red positive for total lipids; B - H. calycifolium Nile blue positive for acid lipids; $\mathrm{C}-H$. patulum Nadi positive for essential oils; D $-H$. x inodorum Dittmar positive alkaloids on glands; $\mathbf{E}-H$. $x$ inodorum Ferric trichloride glands negative and parenchyma positive; $\mathbf{F}-\mathrm{H}$. calycimum under UV light, autofluorescence of phenolic compounds in the cells surrounding the gland. (A, B and F scale bar $=12 \mu \mathrm{m} ; \mathrm{C}, \mathrm{D}$ and $\mathrm{E}$ scale bar $=25 \mu \mathrm{m})$. 


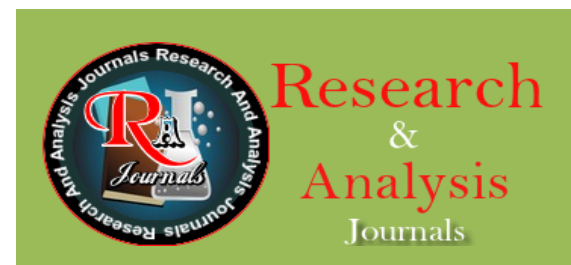

RA Journal of Applied Research

ISSN (e): 2394-6709

||Volume||3||Issue||12||Pages-1303-1314||December-2017||

Index Copernicus ICV: 74.25, DOI: 10.18535/rajar/v3i12.07

Other secondary metabolites, such as the naphthodianthones hypericin and pseudohypericin are characteristic of the black nodules $[7 ; 6]$ which were not present in the leaves of the studied species. This is very important when considering the use of Hypericum species for medicinal purposes, because the different types of secretory structures store distinct types of compounds [40; 45].

All taxa showed clearly bifacial leaves, confirming Metcalf and Chalk [40] data for Hypericum sp. The anatomical characterization provide some differentiation, at the mesophyll level when we consider its total thickness (Fig. 2C) we find three groups: i) $\mathrm{H}$. canariense, $\mathrm{H}$. grandifolium and $\mathrm{H}$. $\mathrm{x}$ inodorum with values below $112 \mu \mathrm{m}$; ii) $\mathrm{H}$. androsaemum and $\mathrm{H}$. patulum with intermediate values up to $154 \mu \mathrm{m}$ and iii) $\mathrm{H}$. calycinum with significantly higher values $206.4 \mu \mathrm{m}$. Metcalf and Chalk [40] also mentioned that the mesophyll usually includes a single layer, occasionally two layers, of palisade tissue. In the six species under study only $\mathrm{H}$. calycinum showed two layers of palisade parenchyma, with a thickness significantly higher than the other species (Fig. 2D). The species grouping as to the thickness of palisade parenchyma is similar to that of the previous set (Fig. 2D). When taking into account the average values of the spongy parenchyma thickness, only two groups significantly different are highlighted (Fig. 2E): i) H. canariense, H. grandifolium and $\mathrm{H}$. $\mathrm{x}$ inodorum with values below $60 \mu \mathrm{m}$, and ii) $\mathrm{H}$. androsaemum, $\mathrm{H}$. patulum and $\mathrm{H}$. calycinum with values up to $90 \mu \mathrm{m}$.

All taxa under study show standard dicotyledonous collateral vascular bundles arrangement, with a bundle sheath surrounding small and larger veins. $H$. calycinum was once again the exception, with fibrous sclerenchyma cells, with very thick cell walls and strongly restricted lumen around xylem vessels, which isolates this vascular tissue from the ground tissue. Metcalfe and Chalk [40] identified solitary and clustered crystals of calcium oxalate between the mesophyll cells in Hypericum species. We also found druses and raphids, but only in $\mathrm{H}$. calycinum and $\mathrm{H}$. androsaemum, respectively.

It is important to note that, in this study, the anatomical characters of the studied species do not fully confirm their taxonomic association in the current sections (Table 1) but further studies are needed.

\section{CONCLUSIONS}

From the micromorphological analysis of the leaves of the studied species there are some differences between them which are new elements reported for the first time and which can be considered as phytognostic characters: the adaxial epidermal cell walls, the amount of epicuticular waxes, the stomata type, the stomata index, the glandular index and the mesophyll and each parenchyma thickness. Most of these characters are not influenced by environmental conditions, might be valid for the accurate and reproducible quality control of the commercial samples, allowing species differentiation and the detection of contaminants and adulterants. Considering our histochemical data, there are no significant differences between these species as they only indicate the presence / absence and the amount of some chemical groups and more data are needed.

\section{ACKNOWLEDGEMIENTS}

We would like to thank Telmo Nunes, Faculdade de Ciências, Universidade de Lisboa, for his technical assistance with SEM; Teresa Vasconcelos, Instituto Superior de Agronomia, 
Universidade de Lisboa for species identification and Silvia Costa for lab assistance.

\section{Funding}

This study was financed by Portuguese National Funds, through FCT - Fundação para a Ciência e a Tecnologia, within the project UID/BIA/ 00329/2013.

\section{REFERENCES}

1. APG III. 2009. An update of the Angiosperm Phylogeny Group classification for the orders and families of flowering plants: APG III. Bot. J. Linn. Soc. 161, 105-121.

2. Crockett, S. L, and Robson, N. K. B. 2011. Taxonomy and chemotaxonomy of the genus Hypericum. Med. Aromatic Pl. Sci. Biotech. 5, 1-13.

3. Ciccarelli, D.; Andreucci, A.C. and Pagni, A. M. 2001a. The "black nodules" of Hypericum perforatum L. subsp. perforatum: morphological, anatomical, and histochemical studies during the course of ontogenesis. Israel J. Pl. Sci. 49, 33-40.

4. Ciccarelli, D., Andreucci, A. C. and Pagni, A. M. 2001b. Translucent glands and secretory canals in Hypericum perforatum L. (Hyperiacaceae): morphological, anatomical and histochemical studies during the course of ontogenesis. Ann. Bot. 88, 637-644.

5. Lotocka, B. and Osinska, E. 2010. Shoot anatomy and secretory structures in Hypericum species (Hypericaceae). Bot. J. Linn. Soc. 163: 70-86.

6. Nahrstedt, A. and Butterweck, V. 1997. Biologically active and other chemical constituens of the herb of Hypericum perforatum L. Pharmacopsychiatry 30 (Suppl.), 129-134.

7. Bombardelli, E. and Morazzoni, P. 1995. Hypericum perforatum. Fitoterapia 66: 43-68.

8. Barnes, J., Anderson, L. A, Phillipson, D. J. 2001. St. John`s wort (Hypericum perforatum): a review of its chemistry, pharmacology and clinical properties. J. Pharm. Pharmacol. 53: 583-600.

9. Viana, A., Rego, J. C., von Poser G, Ferraz, A., Heckler, A.P, Costentin, J. and Rates, S.M.K. 2005. The antidepressantlike effect of Hypericum caprifoliatum Cham \& Schlecht (Guttiferae) on forced swimming test results from an inhibition of neuronal monoamine uptake. Neuropharmacology 49: 1042-1052.

10. Navarini, A. P. G., Schifino-Wittmann, M. T. and Barros I. B. 2008. Caracterização citogenética de populações de Hypericum caprifoliatum Cham. \& Schltdl. (Clusiaceae) em comparação com outras espécies do gênero. Tese Doutoramento Universidade Federal do Rio Grande do Sul.

11. Sánchez-Mateo, C. C. Bonkanka, C. X. and Rabanal, R. M. 2009. Hypericum grandifolium Choisy: A species native to Macaronesian Region with antidepressant effect. J. Ethnopharm, 121: 297-303.

12. Russo, E., Scicchitano, F., Whalley, B. J, Mazzitello C, Ciriaco M, Esposito S, Patan_M, Upton R, Pugliese M, Chimirri S. 2014. Hypericum perforatum: pharmacokinetic, mechanism of action, tolerability, and clinical drug-drug interactions. Phytother. Res. 28: 643-655.

13. Moraes, I. 2007. Caracterização citogenética e da biologia reprodutiva de espécies do género Hypericum L. Tese Dout. Univ. SP. CDD: 576.36234. 
14. Rapisarda, A. Galati, E. M., Tzakou, O., Flores, M. and Miceli, N. 1996. Image analysis. A tool for the drugs investigations. Microsc. Microanal, 44: 1526.

15. Walker, L., Sirvent, T., Gibson, D. and Vance, N. 2001. Regional differences among Hypericum perforatum plants in the northwestern United States. Can. J. Bot. 79: $1248-1255$.

16. Cruz, J. and Teixeira, G. 2003. Caracteres macro e microscópicos em Hyperici herba. Rev. Portuguesa de Farmácia, LII: 165.

17. Maggi F., Ferretti, G., Pocceschi, N., Menghini, L. and Ricciutelli, M. 2004. Morphological, histochemical and phytochemical investigation on the genus Hypericum of the central Italy. Fitoterapia, 75: $702-711$.

18. Stace C. 1989. Plant taxonomy and biosystematics. 2nd ed. London: Edward Arnold.

19. Franco, J. A. 1971. Nova Flora de Portugal, (Continente e Açores), vol. I, 447-453. Lisboa.

20. Núnez, A. F. R.1993. Hypericum L. In: Castroviejo, S., Aedo, C., Cirujano, S., Lainz, M., Montserrat, P., Morales, R., Garmendia,

21. F.M., Navarro, C., Paiva, J., Soriano, C. (Eds.), Flora Iberica, Plantas vasculares de la Península Ibérica e Islas Baleares, vol. III. Real Jardín Botânico, C.S.I.C., 157185, Madrid.

22. Pinto, R. S. 1987. Contribuição para o estudo de compostos flavónicos em espécies de Hypericum da Flora Portuguesa. Tese Doutoramento UP, pp. 193.
23. Cunha P. 2007. Plantas aromáticas em Portugal - caracterização e utilizações. Ed. FCG, Lisboa.

24. Valentão, P., Fernandes, E., Carvalho, F., Andrade, P. B., Seabra, R. M. and Bastos, M. L. 2002. Antioxidant activity of Hypericum androsaemum infusion: scavenging activity against superoxide radical, hydroxyl radical and hypochlorous acid. Biol. Pharm. Bull. 25: 1320-1323.

25. Valentão, P., Dias, A., Ferreira, M., Silva, B., Andrade, P. B., Bastos, M. L. and Seabra, R. M. 2003. Variability in phenolic composition of Hypericum androsaemum. Nat. Prod. Res. 17: 135140.

26. Nogueira, T., Marcelo-Curto, M. J., Figueiredo, A. C., Barroso, J., Pedro, L., Rubiolo, P. and Bicchi, C. 2008. Chemotaxonomy of Hypericum genus from Portugal: Geographical distribution and essential oils composition of Hypericum perfoliatum, Hypericum humifusum, Hypericum linarifolium and Hypericum pulchrum. Biochem. Syst. and Ecol. 36: 40-50.

27. Perrone, R., Rosa, P. D., Castro, O. D. and Colombo, P. 2013. Leaf and stem anatomy in eight Hypericum (Clusiaceae). Acta Bot. Croat. 72: 269-286.

28. European Pharmacopoeia 8.0. 2014. Council of Europe, Strasbourg

29. Johansen, D. A. 1940. Plant microtechnique. McGraw-Hill, New York.

30. Jensen, W. A. 1962. Botanical Histochemistry; principles and practice. CA: Freeman, San Francisco.

31. Lison, L. 1960. Histochemie et cytochemie animals. Principes et méthods, v.1, 2. Gauthier-Villars, Paris. 
32. David, R. and Carde, J. P. 1964. Coloration différentielle des pseudophylles de Pin maritime au moyen réactif de Nadi. Comptes Rendus de l' Academie des Sciences, Paris, Serie D 258: 1338-1340.

33. Hardman, R. and Safowora, E. A. 1972. Antimony trichloride as a test for steroids especially diosgenin and yamogenin in plant tissues. Stain Technol. 47: 205 - 208.

34. Gardner, R. O. 1975. Vanillinhydrochloric acid as a histochemical test for tannin. Stain Technol. 50: 315-317.

35. Pizzolato, P. and Lillie, R. D. 1973. Mayer's Tannic acid-Ferric chloride stain for mucins. J. Histochem. Cytochem. 21: 56-64.

36. Feder, N. and O'Brien, T. P. 1968. Plant microtechnique, some principles and new methods. Am. J. Bot. 55: 123-139.

37. Furr, M. and Mahlberg, P. G. 1981. Histochemical analyses of laticifers and glandular trichomes in Cannabis sativa. J. Nat. Prod. 44:153-159.

38. Teixeira, G., Monteiro, A. and Pepo, C. 2008. Leaf morphoanatomy in Hakea sericeae and $H$. salicifolia. Microsc. Microanal.14:109-110.

39. Ruzin, S. E. 1999. Plant microtechnique and microscopy, 1st ed. Oxford University Press, New York.

40. Esau, K. 1977. Anatomy of Seed Plants, 2nd ed. John Wiley \& Sons, Inc. London.

41. Metcalfe, C. R. and Chalk, L. 1979. Anatomy of the Dicotyledons. 2ed, Vol. 1.
Clarendon Press, Oxford Sciences Publication, Oxford.

42. Teixeira, G. and Diniz, M. 2003. Contribution of micromorphology to the taxonomy of Abrus (LeguminosaePapilionoideae). Blumea 48: 153-162.

43. Dilcher, D. 1974. Approaches to the identifications of angiosperm leaf remains. Bot. Rev. 40: 1-157.

44. Pallioti, A., Cartechini, A. and Nasini, L. 2001. Grapevine adaptation to continuous water limitation during the season. Adv. Hort. Sci. 15: 39-45.

45. Bottega, S., Garbari, F. and Pagni, A. M. 2004. Hypericum elodes L. (Clusiaceae): the secretory structures of the flower. Isr. J. P1. Sci., 52: 51-57.

46. Fahn, A. 1979. Secretory tissues in vascular plants. Ac. Press. London.

47. Costa, T. P. 1985. Bolsas secretoras de Ruta chalepensis L., ontogenia e secreção. Dissertação de Doutoramento. Faculdade de Ciências da Universidade de Lisboa.

48. Bottega, S., Garbari, F. and Pagni, A. M. 2000. Secretory structures in Hypericum elodes L. (Hypericaceae). I. Preliminary observations. Soc. Tosc. Sci. Nat. Mem., Serie B. 106: 93-98.

49. Harborne, J. B. 1993. Introduction to ecological biochemistry. 4th ed. Ac. Press. London.

50. Harborne, J. B. 1997. Plant secondary metabolism. In: Crawley MJ. ed. Plant ecology. 2nd ed. Blackwell Publ. Berlin. 132-155. 